\title{
THE USE OF SISAL FIBRE AS REINFORCEMENT IN CEMENT BASED COMPOSITES
}

\author{
Romildo Dias Tolêdo Filho ${ }^{1}$, Kuruvilla Joseph ${ }^{2}$, Khosrow Ghavami ${ }^{3}$ \& George Leslie England ${ }^{4}$
}

\begin{abstract}
The inclusion of fibre reinforcement in concrete, mortar and cement paste can enhance many of the engineering properties of the basic materials, such as fracture toughness, flexural strength and resistance to fatigue, impact, thermal shock and spalling. In recent years, a great deal of interest has been created worldwide on the potential applications of natural fibre reinforced, cement based composites. Investigations have been carried out in many countries on various mechanical properties, physical performance and durability of cement based matrices reinforced with naturally occurring fibres including sisal, coconut, jute, bamboo and wood fibres. These fibres have always been considered promising as reinforcement of cement based matrices because of their availability, low cost and low consumption of energy. In this review, the general properties of the composites are described in relation to fibre content, length, strength and stiffness. A chronological development of sisal fibre reinforced, cement based matrices is reported and experimental data are provided to illustrate the performance of sisal fibre reinforced cement composites. A brief description on the use of these composite materials as building products has been included. The influence of sisal fibres on the development of plastic shrinkage in the pre-hardened state, on tensile, compressive and bending strength in the hardened state of mortar mixes is discussed. Creep and drying shrinkage of the composites and the durability of natural fibres in cement based matrices are of particular interest and are also highlighted. The results show that the composites reinforced with sisal fibres are reliable materials to be used in practice for the production of structural elements to be used in rural and civil construction. This material could be a substitute asbestos-cement composite, which is a serious hazard to human and animal health and is prohibited in industrialized countries. The production of sisal fibres as compared with synthetic fibres or even with mineral asbestos fibres needs much less energy in addition to the ecological, social and economical benefits.
\end{abstract}

Key words: composite material, natural fibres, concrete, mortar, strength, stiffness, durability

\section{USO DAS FIBRAS DE SISAL COMO ELEMENTOS DE REFORÇO DE COMPÓSITOS A BASE DE CIMENTO}

\footnotetext{
RESUMO

A inclusão de fibras em concretos, argamassas e pastas de cimento melhora propriedades básicas desses materiais tais como a tenacidade na fratura, a resistência à flexão, ao impacto, à choques térmicos e à desagregação. Nos últimos anos tem se observado, em todo o mundo, um grande interesse na aplicação de materiais compósitos, com matrizes a base de cimento, reforçados com fibras vegetais

${ }^{1}$ Professor of the Civil Engineering Department-COPPE, Federal University of Rio de Janeiro. Address: P.O. Box 68506, CEP 21945 - 970, Rio de Janeiro, RJ, Fone: (021) 560 5315, R. 206, Fax: (021) 280 9545, E-mail: toledo@ labest.coc.ufrj.br

${ }^{2}$ Visiting Professor of the Department of Materials Engineering, Federal University of Paraíba. Address: Av. Aprígio Veloso, 882, Bodocongó, CEP 58109 - 700, Campina Grande, PB, E-mail: joseph@ dca.ufpb.br, Fone: (083) 310 1183, Fax: (083) 3101178. Permanet address: Department of Chemistry, St. Berchmans'college, Changanacherry, Kerala, India.

${ }^{3}$ Professor of the Civil Engineering Departament, PUC-Rio, Rua Marquês de São Vicente, 225, Gávea, CEP 22453 - 900 , Rio de Janeiro, RJ, E-mail: ghavami@civ.puc-rio.br

${ }^{4}$ Professor of the Civil Engineering Department, Imperial College of Science Tecnology and Medicine, Imperial College Road, SW7 2BU, London - U.K. E-mail: england@ic.ac.uk
} 
tais como sisal, juta, fibra de coco, fibra de bambu e celulose. Essas fibras têm sido consideradas potencialmente atrativas como reforço de matrizes a base de cimento devido a sua disponibilidade, baixo custo e do baixo consumo de energia gasto na sua produção. No presente artigo, as propriedades gerais dos compósitos são descritas em relação ao volume de fibras, comprimento, resistência e rigidez. O evolução cronológica do uso de fibras de sisal como reforço de matrizes a base de cimento é reportado e dados experimentais são apresentados para ilustrar o comportamento dos compósitos. Uma rápida descrição do uso desses compósitos como elementos de construção é também feita. A influência da presença de fibras de sisal na retração plástica e na resistência à tração, compressão e flexão no estado endurecido de matrizes a base de cimento é discutida. A fluência e a retração por secagem dos compósitos e a durabilidade das fibras vegetais na matriz alcalina são características relevantes e são também discutidas. Os resultados apresentados mostram que os compósitos reforçados com fibras de sisal podem ser usados com segurança na produção de elementos estruturais visando seu emprego nas construções civis e rurais. Esse material pode ser usado, por exemplo, como substituto dos produtos a base de fibras de asbestos os quais podem trazer danos a saúde de seres humanos e animais e que são proibidos, por lei, nos países industrializados. A produção das fibras de sisal, quando comparada com a das fibras sintéticas ou minerais, requer uma quantidade energia muito menor, além dos benefícios ecológicos, sociais e econômicos.

Palavras-chave: compósitos, fibras naturais, concreto, argamassa, resistência, rigidez, durabilidade

\section{INTRODUCTION}

Fibres have been used to toughen bricks and pottery since the very beginning of civilization, but only in the last twenty five years have the principles of fibre reinforcement of brittle matrices began to be scientifically understood. Initially, it was suggested that the cracking strain of brittle matrices, such as cement paste mortar and concrete, could be significantly increased by using closely spaced fibres (Romauldi \& Batson, 1963). The experimental studies showed that the stress at which a brittle matrix will crack can be slightly increased by using high modulus fibres but, in general, the cracking strain of the matrix remains unaltered. Considerable modification in the behavior of the material was observed once the matrix has been cracked. The fibres bridge across the cracks and so provide post-cracking ductility. Although the strain at cracking does not increase due to fibre reinforcement, the tensile strain at rupture does, resulting in a tough material with high resistance to impact loading (Bentur \& Mindess, 1990).

A wide variety of fibres have thus been used with cement based matrices. They include metallic fibres, polymeric fibres, mineral fibres and vegetable fibres. The cement matrices can consist of paste, mortar or concrete. Most of the developments with fibre reinforced concrete involve the use of ordinary Portland cement. However, high alumina cement, cement with additives such as fly ash, slag, silica fume, etc. have also been used generally to improve the durability of the composite or to minimize chemical interactions between the fibres and matrix.

Fibres can be added to cement based matrices as primary or secondary reinforcement. Fibres work as primary reinforcement in thin products in which conventional reinforcing bars cannot be used. In these applications, the fibres act to increase both the strength and the toughness of the composite. In components such as slabs and pavements, fibres are added to control cracking induced by humidity or temperature variations and in these applications they work as secondary reinforcement (Tolêdo Filho, 1997).

Vegetable fibres, including sisal, coconut, jute, bamboo and wood fibres, are prospective reinforcing materials and their use until now has been more empirical than technical. They have been tried as reinforcement for cement matrices in developing countries mainly to produce low-cost thin elements for use in housing schemes. Vegetable fibres require only a low degree of industrialization for their processing and in comparison with an equivalent weight of the most common synthetic reinforcing fibres, the energy required for their production is small and hence the cost of fabricating these composites is also low (Aziz et al., 1984). In addition, the use of a random mixture of vegetable fibres in cement matrices leads to a technique that requires only a small number of trained personnel in the construction industry. The use of such fibres in concrete provides an exciting challenge to the construction industry for housing, for providing roofing sheets and to contribute to the rapid development of a country's infrastructure. Vegetable fibre cement composites thus pose the challenge and the solution for combining unconventional building materials with traditional construction methods

\section{BEHAVIOR OF CEMENT BASED COMPOSITES}

In cement based composites the two major roles played by the fibres are to improve the toughness and the post-cracking performance of the matrices. There is also some changes created to the pre-cracking behavior of the hardened matrix, which help to define the composite action. Fibre content (\% by volume), ratio of fibre modulus, $\mathrm{E}_{\mathrm{f}}$, to the matrix modulus, $\mathrm{E}_{\mathrm{m}}$, and the ratio of fibre strength, $\sigma_{\mathrm{f}}$, to the matrix strength, $\sigma_{\mathrm{m}}$, all influence the performance of the composite before and after cracking (England \& Tolêdo Filho, 1997; Tolêdo Filho, 1999). In a welldesigned composite the fibres can serve two functions in the post-cracking zone (Bentur \& Mindess, 1990): (i) to increase the strength of the composite over that of the matrix by providing a means of transferring stresses and loads across the cracks and (ii) to increase the toughness of the composite by providing energy absorbing mechanisms related to the debonding and pull-out processes of the fibres bridging the cracks.

Knowledge of fibre properties is important for design purposes. Fibre tensile strength is usually higher than the matrix strength and becomes influential in post-cracking behavior only when long fibres are used (i.e. long enough to prevent complete pull-out at the time of first cracking) or when the matrix is of high 
strength and a small volume fraction of fibres is used. A high ratio of fibre modulus to matrix modulus facilitates stress transfer from the matrix to the fibre. Fibres having large values of failure strain give high extensibility in composites. Problems associated with fibre debonding at the fibre-matrix interface are prevented by having a lower Poisson's ratio (Beaudoin, 1990).

\section{INFLUENCE OF FIBRE MODULUS, $\mathrm{E}_{\mathrm{F}}$, ON COMPOSITE MODULUS, $\mathrm{E}_{\mathrm{C}}$}

Generally the composite modulus, $\mathrm{E}_{\mathrm{c}}$, will change in the direction towards the fibre modulus, $\mathrm{E}_{\mathrm{f}}$. Simple mixture models based on volume fraction of fibres $\mathrm{V}_{\mathrm{f}} / \mathrm{V}_{\mathrm{c}}$ (where $\mathrm{V}_{\mathrm{c}}$ is the bulk volume and $\mathrm{V}_{\mathrm{f}}$ is the volume fraction of fibres) allow $\mathrm{E}_{\mathrm{c}}$ to be estimated from parallel or series combinations of fibres and matrix as shown in Figure 1.
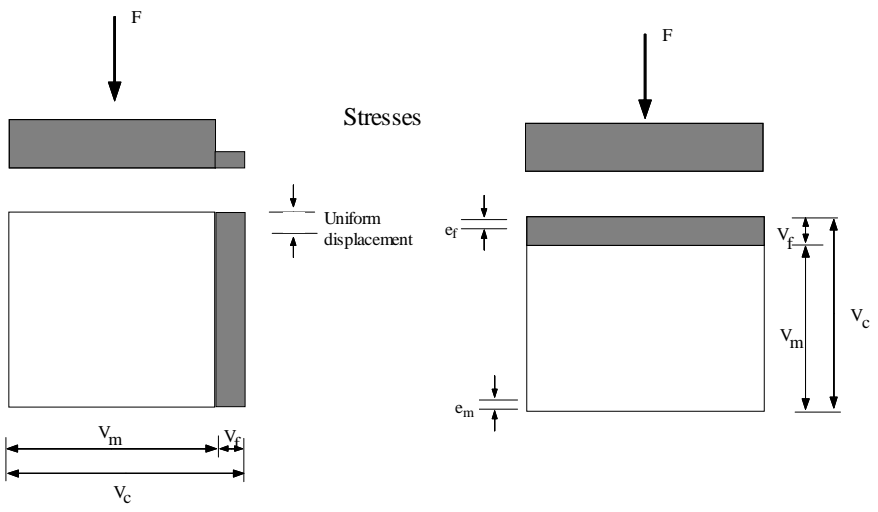

Figure 1. (A) Parallel model, and (B) Series model, for estimating overall effective modulus of composite (England \& Tolêdo Filho, 1997)

Compatibility of strains for the parallel model leads to:

$$
\mathrm{E}_{\mathrm{c}} / \mathrm{E}_{\mathrm{m}}=\left(1-\mathrm{V}_{\mathrm{f}} / \mathrm{V}_{\mathrm{c}}\right)+\left(\mathrm{E}_{\mathrm{f}} / \mathrm{E}_{\mathrm{m}}\right)\left(\mathrm{V}_{\mathrm{f}} / \mathrm{V}_{\mathrm{c}}\right)
$$

and equilibrium of stresses for each phase in the series model leads to:

$$
\mathrm{E}_{\mathrm{m}} / \mathrm{E}_{\mathrm{c}}=\left(\mathrm{E}_{\mathrm{m}} / \mathrm{E}_{\mathrm{f}}\right)\left(\mathrm{V}_{\mathrm{f}} / \mathrm{V}_{\mathrm{c}}\right)+\left(1-\mathrm{V}_{\mathrm{f}} / \mathrm{V}_{\mathrm{c}}\right)
$$

These models are usually considered to provide upper and lower bounds to the ratio $\mathrm{E}_{\mathrm{c}} / \mathrm{E}_{\mathrm{m}}$ because the real material is composed of complex series and parallel combinations of the fibre and matrix moduli internally. Usually,

$$
1.1 \text { (high modulus fibres) } \geq \mathrm{E}_{\mathrm{c}} / \mathrm{E}_{\mathrm{m}} \geq 0.9 \text { (low modulus fibres) }
$$

Eqs. (1) and (2) can be modified to allow for the random orientation of fibres by the introduction of efficiency factors (Argon \& Shack, 1975) which multiply $\mathrm{V}_{\mathrm{f}}$ of the fibre component of the model.

\section{EFFECT OF FIBRE MODULUS ON STRENGTH OF COMPOSITE}

Compressive strength is essentially unaffected by the inclusion of a low fraction $(<0.5 \%)$ of low modulus fibres
$\left(\mathrm{E}_{\mathrm{f}} / \mathrm{E}_{\mathrm{m}}<1\right)$. At a volume fraction of $2 \%$ to $3 \%$ the compressive strength can be reduced by about $25 \%$ to $30 \%$. However, for $\mathrm{E}_{\mathrm{f}}$ $\mathrm{E}_{\mathrm{m}}>1$ there is generally some increase in compressive strength. For volume fractions of steel fibres up to $1.5 \%$ compressive strength increases of up to $25 \%$ have been recorded for normal concrete (Balagaru \& Shah, 1992). For high fibre contents (around $10 \%$ ) up to three-fold increase of matrix strength can be achieved for slurry infiltrated concrete. This increase of strength results from the high stiffness of the fibres and the internal lateral confinement by the stiff fibres.

Except at very high fibre contents, the tensile strength of the composite is dominated by the matrix strength. Stiff fibres produce some increase in strength, while soft fibres usually have little effect on the composite. After first cracking, load is transferred to the fibres at the crack site and one of several types of behavior may then ensue, depending on the strength, volume fraction and length of fibres. Figure 2 describes the preand post-cracking behavior of a tensile test specimen. Four different responses are shown for different fibre contents (Figure 3). Complete separation of parts A and B of the composite occurs at $\mathrm{a}, \mathrm{b}, \mathrm{c}$ and $\mathrm{d}$ for the different concentrations of the fibres. 0 -a corresponds to brittle failure of the matrix only. $0-\mathrm{a}-\mathrm{b}$ reflects the performance of a composite with low concentration of fibres; namely a concentration which is too low to support

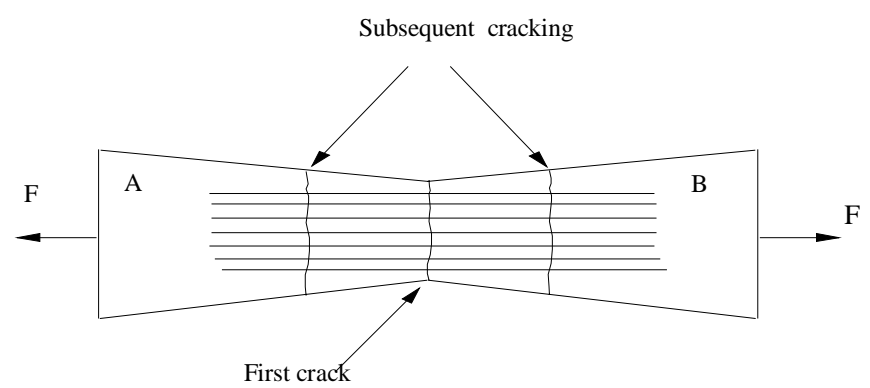

Figure 2. Fibre reinforced composite under tensile load

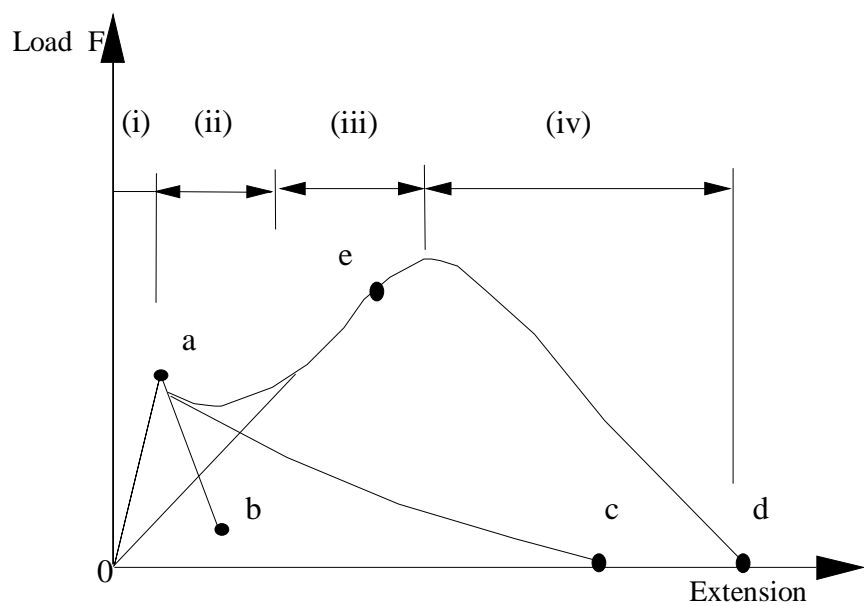

Figure 3. Load-extension behaviour of fibre reinforced cement composite for various fibre concentrations and lengths. 0 -a is unreinforced material response; brittle fracture occurs at point a. 0-a-b; insufficient fibre content. 0-a-c; typical response for short fibres $(<15 \mathrm{~mm})$ and volume concentrations $1 \%$ to $2 \%$. Unstable behaviour with fibre pull-out. 0 -a-d; normal response for longer fibres (typically $>25 \mathrm{~mm}$ ). Stable behaviour followed by pull-out. 0 -a-e; similar to previous response but for weaker fibres which fracture before pull-out (England $\&$ Tolêdo Filho, 1997) 
the force $\mathrm{F}$ after the first cracking of the matrix. Fibre fracture occurs immediately following cracking of the matrix. 0 -a-c corresponds to an amount of fibres, which just debonds completely immediately after cracking. This behavior is typical of short fibres. Frictional slip occurs with declining $\mathrm{F}$ as the fibre embedment length reduces; complete pull-out occurs at point c. Larger fibre volume fraction leads to the behavior shown by the path 0 -a-d for which four components of extension are identified: (i) Elastic behavior of the matrix and fibre before cracking. (ii) Elastic behavior and initial debonding of fibres close to the matrix fracture site after cracking. (iii) Further unbonding of fibres, accompanied by frictional slip of all unbonded lengths, during the increasing force phase of pull-out. Extra matrix cracking may also occur during this phase. (iv) Continuing pull-out of fibres after reaching the fully unbonded stage. For long fibres which fracture before complete pull-out a response of the form 0 -a-e is possible. This however, is not usually the form of response, which is sought if high toughness is the objective.

To some extent, flexural behavior reflects the tensile behavior, although more redistribution of load between fibres occurs in this case. After cracking considerable ductility is usually observed when sufficient fibres are present. Peak strength may exceed the strength at first cracking by a factor of two or more, depending on the volume fraction of fibres and their strength. For fibres which do not fracture or pull-out at first cracking but undergo pull-out behavior thereafter, an increase of strength is frequently observed as pull-out develops and more and more load is transferred to the fibre network. This becomes the important mode of behavior, which governs flexural failure when high toughness is required. When insufficient fibres are present unstable flexural behavior results, with pull-out occurring under a declining load regime.

\section{SISAL FIBRE REINFORCED CEMENT BASED COMPOSITES}

\section{Materials}

The extraction methods, microstructure and properties of sisal fibres have been discussed elsewhere (Joseph et al., 1999). The cement matrices can consist of paste, mortar or concrete. Most of the studies on sisal fibre concrete involve the use of ordinary Portland cement. However, high alumina cement, cement with additives such as fly ash, slag, silica fume have also been used to improve the durability of the composites (Gram, 1983; Tolêdo Filho, 1997).

\section{Production technology}

The production technologies available include (Bentur \& Mindess, 1990): (i) combining fibres with matrix in a pan mixer as if the fibres were an extra ingredient in the common method of producing a cementitious mix; (ii) simultaneously spraying fibres and cement slurry onto the forming surface to produce thin products; (iii) fibre-reinforced concrete; (iv) dispersal of fibres in a cement slurry which is then dewatered to produce thin products; (v) hand-laying fibres, in the form of mats or fabrics, in moulds, impregnating them with a cement slurry and then vibrating or compressing the mix to produce a dense material with high fibre content; and (vi) impregnating continuous fibre mats and fabrics with a cement slurry by passing them through a cement bath in a continuous process.

\section{Physical and mechanical properties of the composites}

Joseph et al. (1999) reported that sisal is one of strongest vegetable fibres and several studies have been reported in the literature based on its use as reinforcement in cement matrices (BRS, 1970; Nilsson, 1975; Zonsveld, 1975; Mukherjee \& Satyanarayana, 1984; Gram, 1983; Aziz et al., 1984).

Studies of sisal fibre reinforced concrete were started in Sweden in 1971 by Nilsson (1975). Cut fibres with a length of 10$30 \mathrm{~mm}$ were cast into beams and an improvement in the tensile strength in bending was observed for fibre reinforced specimens. It was found that toughness increased markedly when continuous fibre were used.

In 1977 the Building Research Unit (BRU) in Dar es Salaam started collaboration on the development of roof sheets on natural fibre reinforced concrete with the Swedish Cement and Concrete Research Institute (Cappelen, 1978; BRU, 1978; Mwamila, 1979, 1987; Mawenya \& Mwamila, 1979). Test sheets were manufactured for durability experiments. A special roof sheet profile was developed and several buildings in Dar es Salaam have been provided with sisal fibre reinforced concrete roofs.

The use of sisal fibre as reinforcement in cement paste and concrete have been reported by Swift and Smith $(1978 ; 1979 a)$. Their results on the flexural static strength (Table 1) and toughness of beams made of cement based matrices reinforced indicated that remarkably high strengths can be achieved using suitable mixing and casting techniques with optimum fibre volume fraction, although in Table 1 the modulus of rupture is found for different ages. They also found that impact resistance can be improved by the addition of sisal fibres. Several application of this material was suggested for low-cost housing and they produced corrugated sheets of $2140 \times 690 \times 7 \mathrm{~mm}$ in different ways to optimize the processing technique.

A model of the flexural behavior of a cement-based composite reinforced with low modulus sisal fibres was derived by Swift and Smith (1979b) based on the stress distribution shown in Figure 4.

For low modulus fibres it was assumed that flexural failure occurs through failure at the compressive surface, the apparent modulus of rupture being:

$$
\sigma_{\mathrm{b}}=6 \mathrm{M} / \mathrm{bd} \mathrm{d}^{2}=\left(2 \sigma_{\mathrm{T}}+3 \chi \sigma_{\mathrm{CU}} \varphi^{2}\right) /(1+\varphi)^{2}
$$

Where

$\varphi \quad$ - dimensionless parameter defined as $\varphi=\mathrm{E}_{1} \varepsilon_{\mathrm{comp}} / \sigma_{\mathrm{cu}}$

$\sigma_{\mathrm{cu}} \quad$ - stress at tensile surface at flexural failure defined as $\sigma_{\mathrm{cu}}=\left(2 \mathrm{E}_{1} \chi \sigma_{\text {comp }} \varepsilon_{\text {comp }}\right)^{1 / 2}$

$\sigma_{\text {comp }}$ - compressive failure stress of the composite

$\varepsilon_{\text {comp }}$ - compressive failure strain of the composite

$\mathrm{E}_{1}$ - effective modulus of cracked region of the beam defined as $\mathrm{E}_{1}=\beta \mathrm{V}_{\mathrm{f}} \mathrm{E}_{\mathrm{f}}$

$\beta \quad$ - fibre orientation factor

$\chi \quad$ - stress block factor chosen such that, by replacing the actual non-linear compressive zone by a region of constant stress $\chi \sigma_{\mathrm{CU}}$, the same compressive force and bending moment are obtained. $\chi$ is expected to lie within the range 0.4 to 0.7 .

$\mathrm{V}_{\mathrm{f}} \quad$ - fibre volume fraction

$E_{f} \quad$ - elastic modulus of fibre

d - depth of beam

b - width of beam

M - failure moment of beam 
Table 1 - Modulus of rupture of sisal fibre reinforced concrete (Swift \& Smith, 1978)

\begin{tabular}{cccccc}
\hline $\begin{array}{c}\text { Mix proportion } \\
\text { (cement:sand:coarse aggregate:w/c) }\end{array}$ & $\begin{array}{c}\text { Fibre content } \\
(\%)\end{array}$ & $\begin{array}{c}\text { Fibre length } \\
(\mathrm{mm})\end{array}$ & $\begin{array}{c}\text { Curing period } \\
(\text { days })\end{array}$ & $\begin{array}{c}\text { Specimen Size } \\
(\mathrm{mm})\end{array}$ & $\begin{array}{c}\text { Modulus of rupture } \\
(\mathrm{MPa})\end{array}$ \\
\hline $1: 1.8: 2.4: 0.57$ & 3 & 50 & 28 & $100 \times 100 \times 500$ & 3.70 \\
$1: 1.8: 2.4: 0.57$ & 2 & 50 & 35 & 14 & $100 \times 100 \times 500$ \\
$1: 0.78: 1.82: 0.36$ & 5 & 50 & 7 & $80 \times 100 \times 500$ & 4.80 \\
$1: 3: 0: 0.50$ & 2 & 50 & 28 & $80 \times 80 \times 300$ & 3.70 \\
$1: 3: 0: 0.50$ & 1 & 50 & 300 & 3.30 \\
\hline
\end{tabular}

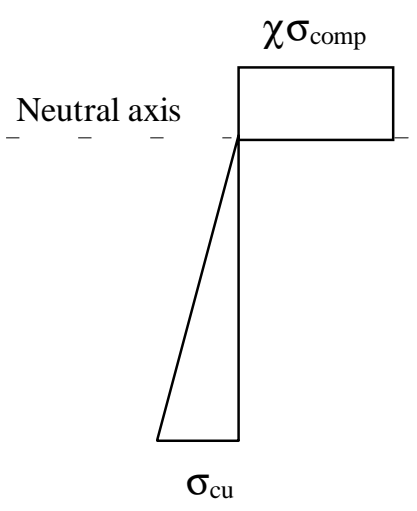

Figure 4 - Stress distribution for low modulus fibre reinforced cement composite at flexural failure (Swift \& Smith, 1979b)

The conditions under which Eq. 4 is valid are:

a) the fibres must be sufficiently long for general debonding not to have taken place near the tensile surface prior to flexural failure of the beam,

b) the strength and quantity of fibres must be sufficient for them not to fail in tension prior to compressive failure of the composite, i.e.:

$$
\beta \mathrm{V}_{\mathrm{f}} \sigma_{\mathrm{fu}}>\sigma_{\mathrm{cu}}
$$

or

$$
\mathrm{V}_{\mathrm{f}}>2 \mathrm{E}_{\mathrm{f}} \chi \sigma_{\text {comp }} \varepsilon_{\text {comp }} / \beta\left(\sigma_{\mathrm{fu}}\right)^{2}
$$

where $\sigma_{f u}$ is the ultimate tensile strength of fibre.

According to Gram (1983) and Partek (1979) conducted a detailed study on the possibilities of using sisal fibre reinforced concrete for roof sheets and sandwich elements with cellular concrete. The aim was to manufacture these products on a large scale in a highly mechanized process embracing spray concrete technology. Durability studies were conducted using accelerated tests in a climate box as a function of degree of reinforcement and the pre-treatment of the fibres. The pre-treatment embraced acid mercerisation, $\mathrm{NH}_{3}$ treatment, Ca stearate treatment, PVA treatment, plastic treatment. It was found that sisal fibre reinforced concrete became brittle in all cases after storage in the climate box.

Persson \& Skarendh (1980) have studied sisal fibre-concrete for roofing sheets and other purposes. The influence of matrix strength, fibre content and fibre arrangement on the flexural strength of the composite was investigated. They concluded that an increase in matrix quality, keeping constant the volumefraction of fibres, increases the flexural strength of the composite. When changing the volume-fraction of continuous fibres, but keeping the quality of the matrix constant, an increase in the post-cracking behavior was observed. Product design, production and building techniques were also investigated.

Aziz et al. (1981) has discussed prospects for natural fibre reinforced concrete in construction. Factors affecting the properties in the fresh and hardened states were critically discussed. They concluded in general that economical and efficient methods of fibres extraction, treatment, conversion to efficient geometrical forms, dispersion in the concrete mix, casting, placing and curing are highly essential. It was recommended that standard test procedures must be established to manufacture quality products.

Bessell \& Mutuli (1982) have studied the interface bond strength of sisal-cement composites using a tensile test. The interfacial bond strength was computed from 46 specimens and the mean bond strength was found to be 0.6 MPa with a standard deviation of $0.26 \mathrm{MPa}$.

Loss of toughness with age was observed by Gram (1983, 1988) and Bergströn and Gram (1984) for sisal fibre reinforced mortar composites. In his studies, Gram stored specimens in four different environments: (i) in water, (ii) dry in a laboratory room at $20^{\circ} \mathrm{C}$ and $50 \%$ R.H (iii) specimens stored alternately wet and dry, and (iv) outdoors. Three point's flexural tests were carried out in specimens measuring $55 \times 200 \times 8 \mathrm{~mm}$ with a mortar composed of cement, aggregate $(0-2 \mathrm{~mm})$ and water in weight ratios of 1:2:0.5. A post-cracking parameter, $\mathrm{B}$, was selected as a criterion of the toughness of the composite. The parameter $\mathrm{B}$ is determined from the maximum post-cracking load using the bending formula when the stress-strain curve show a strainhardening characteristic or from the load measured at a strain of $1 \%$ when the stress-strain curve shows a strain-softening characteristic. The obtained results indicated that the specimens stored either dry or permanently in water nearly retained their toughness for at least two years. Specimens stored alternately wet and dry and outdoors lost their toughness within 1-2 years (Tables 2, 3, 4 and 5).

To enhance the durability performance of sisal fibre reinforced cement based composites, Gram (1983) treated the sisal fibres with blocking agents such as sodium silicate, sodium sulfite, magnesium sulfate, iron or copper compounds, barium and sulfite salts, but none of them improved the durability of the fibre in a cement matrix. Fibre impregnation with water repellent agents was also used by Gram but apart from formine and stearic acid (that led to a retardation of the embrittlemet tendency of the composites) all other treatments (PVA, amide wax, silicon oil, tar, rubber latex, asphalt) did not prevent the fibre from being mineralized. 
Table 2. Values for B in MPa at different ages for air stored specimens reinforced with short sisal fibres with varying lengths and volume proportions (Gram, 1983)

\begin{tabular}{cccccc}
\hline \multirow{2}{*}{$\begin{array}{c}\text { Fibre length } \\
(\mathrm{mm})\end{array}$} & Fibre volume & \multicolumn{4}{c}{ Time (days) and B } \\
\cline { 3 - 6 }$(\%)$ & 28 & 91 & 365 & 730 \\
\hline 15 & 2.87 & 3.5 & - & - & 2.1 \\
30 & 1.03 & 2.2 & - & - & - \\
30 & 1.96 & 2.4 & 2.9 & 1.7 & 1.4 \\
50 & 1.09 & 2.8 & - & - & 1.1 \\
50 & 1.76 & 2.5 & 3.1 & 2.1 & 1.4 \\
\hline
\end{tabular}

Table 3. Values for B in MPa at various ages for specimens reinforced with short sisal fibres with varying lengths and volume proportions, stored in a water bath with a temperature of $20^{\circ} \mathrm{C}$ (Gram, 1983)

\begin{tabular}{cccccc}
\hline Fibre length & Fibre volume & \multicolumn{4}{c}{ Time (days) and B } \\
\cline { 3 - 6 }$(\mathrm{mm})$ & $(\%)$ & 28 & 91 & 365 & 730 \\
\hline 30 & 1.96 & 2.6 & 2.8 & 2.3 & 3.0 \\
50 & 1.76 & 2.3 & 3.5 & 2.2 & 1.4 \\
\hline
\end{tabular}

Table 4. Values for B in MPa at various ages for specimens reinforced with short sisal fibres submitted to alternating wet and dry conditions (Gram, 1983)

\begin{tabular}{lccccccc}
\hline Fibre & $\begin{array}{c}\text { Fibre length } \\
\text { Type }\end{array}$ & $\begin{array}{c}\text { Fibre volume } \\
(\mathrm{mm})\end{array}$ & $(\%)$ & \multicolumn{5}{c}{ Time (days) and B } \\
\cline { 4 - 8 } & 30 & 1.96 & 28 & 91 & 365 & 730 & 1186 \\
\hline Sisal & 50 & 1.76 & 2.5 & 2.2 & 2.4 & 0.5 & - \\
Sisal & 50 & &
\end{tabular}

Table 5. Values of B in MPa for specimens reinforced with long aligned sisal fibres after various lengths of time conditioned outdoors in Dar es Salaam, Bangkok, Addis Ababa and Stockholm (Gram, 1988)

\begin{tabular}{lccccc}
\hline \multirow{2}{*}{ Locality } & \multicolumn{5}{c}{ Time (days) and B } \\
\cline { 2 - 6 } & 28 & 200 & 365 & 730 & 1460 \\
\hline Addis Ababa & 15.0 & 1.4 & 1.9 & - & - \\
Bangkok & 10.5 & - & 0.5 & 0.7 & - \\
Dar es Salaam & 12.5 & 0.3 & - & - & - \\
Stockholm & 30.7 & 6.9 & - & - & 4.8 \\
\hline
\end{tabular}

Sealing the matrix pores, admixing small beads of wax or powder of zinc stearate in the fresh mortar, or impregnating the hardened product with sulfur showed promising results (Gram, 1983). Treatment of the matrix to reduce its alkalinity was also studied by Gram. The products studied included: high alumina cement, replacement of OPC by silica fume, slag, fly ash and natural pozzolanas (rice husk ash, scoria, pumice, and diatomite). Replacing $45 \%$ of cement with silica fume eliminated the loss of toughness of the composite. A marked improvement was also observed when using high alumina cement and natural pozzolanas (Table 6). With fly ash and slag replacement, however, no significant improvement was obtained.

Guimarães $(1984,1987)$ has studied the influence of fibre length and volume fraction, matrix proportioning and casting processes on the flexural strength, water absorption and specific gravity of the sisal fibre-cement composites. An increase in the flexural strength and better crack distribution was achieved by the incorporation of sisal fibres in the cement matrices. They have studied the influence of casting pressure on the flexural properties of the composites and it was found that 2.2 MPa was the optional value.
Morrissey \& Coutts (1985) have studied interfacial bonding between sisal fibres and cement matrices. To determine the critical length of embedment, fibre lengths ranging from 10 to $60 \mathrm{~mm}$ were considered. It was observed that in cement composites the critical length of embedment for sisal fibre was approximately $30 \mathrm{~mm}$.

Swift (1985) has reviewed the potential applications of sisalcement composites in rural Africa. He concluded that these composites could be a suitable material for many aspects of rural area development.

Mwamila (1985) has studied the behavior of sisal twines as main reinforcement in concrete beams. The flexural performance was investigated under static, repeated and sustained loading. An attempt to improve the beams performance was made by the use of short sisal fibre to supplement the twines reinforcement. He concluded that the concrete beams reinforced with twines presented poor cracking behavior, developing wide cracks and suffering significant strength losses upon each crack occurrence. The residual and permanent deformations and crack widths under repeated and sustained loads were also very significant. The use of short sisal fibres to supplement the twines improved tensile toughness and, through bond enhancement and stress redistribution, improved the tensile stiffen effect of the composite matrix. As a result the cracks formed were smaller, their propagation slow and the troughs in the strength-deflection curve removed. Further, the deformations under repeated and sustained load were significantly reduced.

Baluch et al. (1987) have studied the fracture characteristics of sisal fibre reinforced concrete composites and a theoretical fracture model equation was developed to predict the crack resistance curve. They observed that the concept of critical crack opening angle (CCOA) was applicable to sisal fibre reinforced concrete and that for volume fraction and fibre length smaller than $3 \%$ and $40 \mathrm{~mm}$, respectively, the obtained model provided good results.

Carvalho Filho (1990) has studied the mechanical behavior of sisal fibre reinforced mortar composites as a function of fibre length, fibre content and humidity conditions of fibres (dry and saturated). A significant improvement in impact properties was noticed in all cases.

Schafer \& Brunssen (1990) have developed a new low-cost, lost formwork system for floor slabs based on sisal fibre reinforced-cement composites as substitute for structural timber and have studied the load-carrying behavior of the above system having different geometrical shapes. It was observed that among various forms arch-shaped units (sectroids) placed in between prefabricated beams have turned out to be the most favorable. In general it was concluded that the production technique of the sisal fibre reinforced units is so simple that unskilled workers can be employed; the units are strong enough to carry the weight of the fresh concrete and all the loads which may occur during the casting of the slab itself. An appropriate bond quality between formwork and in-situ concrete can be easily obtained with the help of a simple tool. Due to the high cement content, the surface of the units is nearly gas-tight, so that it guarantees a high degree of corrosion protection.

Canovas et al. (1990, 1992) have studied the durability of sisal fibre reinforced Portland cement mortars composites. To improve the composite durability they added colophony, tannin and montan wax to the mortar matrix. All mixes had the same consistence. Effects produced by these additives on the mortar porosity, water absorption and flexural and compression strength were studied and compared with those of the control mortar. The results obtained indicated a reduction of about $70 \%$ in water 
Table 6. Toughness values for parameter B for specimens with various percentages of silica fume, pumice, scoria, diatomite and rice husk ash and reinforced with sisal fibres stored outdoors in Dar es Salaam, Stockholm Bangkok and Addis Ababa (Gram, 1983)

\begin{tabular}{|c|c|c|c|c|c|c|c|}
\hline \multirow{2}{*}{$\begin{array}{c}\text { Cement replacement } \\
(\%)\end{array}$} & \multirow[t]{2}{*}{ Locality } & \multicolumn{6}{|c|}{ Number of days and B (MPa) } \\
\hline & & 0 & 200 & 365 & 540 & 730 & 1460 \\
\hline Silica fume, 15 & Stockholm & 35.6 & 12.1 & - & - & - & - \\
\hline Silica fume, 20 & Stockholm & 30.8 & 10.6 & - & - & - & 9.6 \\
\hline Silica fume, 17 & Dar es Salaam & 24.0 & 12.7 & - & - & - & 8.7 \\
\hline Silica fume, 33 & Dar es Salaam & 32.0 & 24.6 & - & - & - & - \\
\hline Silica fume, 25 & Bangkok & 23.0 & - & - & - & 8.9 & - \\
\hline Silica fume, 40 & Bangkok & 24.4 & - & - & 17.9 & 17.0 & - \\
\hline Silica fume, 25 & Addis Ababa & 12.3 & 11.6 & - & 15.9 & - & - \\
\hline Silica fume, 40 & Addis Ababa & 12.1 & 10.9 & - & 10.6 & - & - \\
\hline Pumice, 40 & Addis Ababa & 7.5 & 6.0 & 10.2 & 8.2 & - & - \\
\hline Scoria, 40 & Addis Ababa & 12.2 & 14.0 & 11.8 & 14.4 & - & - \\
\hline Diatomite, 20 & Addis Ababa & 9.1 & 6.3 & 7.5 & 8.2 & - & - \\
\hline Rice husk ash, 40 & Bangkok & 22.7 & - & 12.4 & 8.3 & 9.6 & - \\
\hline
\end{tabular}

absorption and relative porosity. Depending on the nature of the used additive the mechanical properties could be reduced or increased from 0 to $20 \%$. Impregnation of sisal fibres with organic compounds derived from timber such as tannins, colophony and vegetable oils was also studied. According to the authors these compounds have the characteristics of being agglutinates and hydrophobic, with the capacity to reinforce the weak bonds of the hydrophobic agents of the fibres, filling empty spaces in the fibres and re-coating them externally. The tannins form insoluble compounds with the majority of the metallic salts and they are practically undecomposed and impermeable. They have the capacity of uniting with carbohydrates and refilling the amorphous regions, thus protecting the fibres from the penetration of water. Colophony is a non-volatile fraction of pine resin. It is insoluble in water but soluble in the majority of fats and organic solvents. It is composed of $90 \%$ of resinic acids. The vegetable oils are compounds insoluble in water, having the property of spreading as a thin film which ends by polymerizing. The method of impregnation used was double diffusion (hot and cold) carried out in two tanks: in one of them the impregnants were in a hightemperature state $\left(80-100{ }^{\circ} \mathrm{C}\right)$ while in the other they were at room temperature. Various alternate repetitions of this process facilitate the escape of entrapped air and at the same time the free space is filled by the impregnant. In order to obtain a good penetration power, the viscosity of the impregnants ought to be the same as water and this was obtained by the use of a proper solvent, relatively high temperatures and an adequate time of treatment. Table 7 shows the used treatments and the tensile strength and absorption of water of the sisal fibres. In relation to the durability of the composites, the results indicated a slow down in the embrittlement process using the above treatments but did not avoid it completely. Mortar of mix 1:1.5:0.45 reinforced with impregnated and unimpregnated sisal fibres were submitted to accelerated ageing and the flexural strength determined. The accelerated ageing consisted of $3.5 \mathrm{~h}$ of oven heating at $95{ }^{\circ} \mathrm{C}$ followed by $0.5 \mathrm{~h}$ of submersion in water at room temperature; a total of $4 \mathrm{~h}$ was considered as one cycle of ageing. The results obtained from flexural tests carried out after 120 cycles indicated that the specimens reinforced with impregnated fibres presented better results than those obtained with unimpregnated fibres. For example, the specimens reinforced with sisal fibre impregnated with colophony presented a maximum postcracking flexural strength (MPCFS) value of about 3.5 MPa after 120 cycles whereas the specimens with unimpregnated sisal fibres presented a value of about $0.3 \mathrm{MPa}$.

Savastano \& Agopyan (1992) have studied the transition zone of hardened cement paste having sisal fibres. The effects of water-cement ratio (from 0.30 to 0.46 ) and the age of the composite (up to 180 days) on this zone characteristics were analyzed. It was observed that the transition zone of sisal fibrecement paste composites was porous, thick and rich of random portlandite crystals.

Chatveera \& Nimityongskul (1987) have studied the influence of modified rice husk ash (MRHA) on the mechanical properties and durability of sisal pulp reinforced mortar composites as a function of pulp volume fraction. The modification of the normal rice husk ash (RHA) consisted in grinding the RHA to a very high degree of fineness. The results of sisal pulp-mortar composites were compared to those of bamboo and pine composites (Tables 8 and 9). In this study, the water-cement ratio, sand-cement and dosage of superplasticizer

Table 7. Results of studies on impregnated sisal fibres (Canovas et al., 1990)

\begin{tabular}{lccc}
\hline Impregnating agent & Proportion by & Tensile strength & Absorption of water \\
& weight & $(\mathrm{MPa})$ & 570.0 \\
\hline Control & - & 487.0 & 70.0 \\
Colophony + turpentine & $1: 6$ & 530.0 & 33.0 \\
Clove oil + xylene + alcohol + turpentine & $13: 3: 1: 30$ & 407.0 & $14.0-20.0$ \\
Tannin + alcohol + xylene & $1: 30: 1$ & 39.0 \\
\hline
\end{tabular}


Table 8. Physical and mechanical properties of sisal fibre and pulps (Chatveera and Nimityongskul, 1987)

\begin{tabular}{lcccc}
\hline Description & Sisal fibre & Sisal pulp & Bamboo pulp & Pine pulp \\
\hline Diameter (mm) & $0.15-0.26$ & 0.075 & 0.015 & 1.48 \\
Length (mm) & $1200-1500$ & 3.00 & 1.46 & 2.48 \\
Apparent specific gravity & 0.69 & 1.36 & 13.19 & 5.47 \\
Moisture content (\%) & 11.00 & 52.8 & 189.5 & 0.69 \\
Water absorption (\%) & 119.00 & 496.23 & 1245 & 168.8 \\
Tensile strength (MPa) & 297.83 & 20.00 & 12.60 \\
Modulus of elasticity (GPa) & 11.37 & & - \\
\hline
\end{tabular}

Table 9. Moisture content, water absorption, expansion, drying shrinkage, impact resistance and modulus of rupture of pulp-mortar composites (Chatveera and Nimityongskul, 1987)

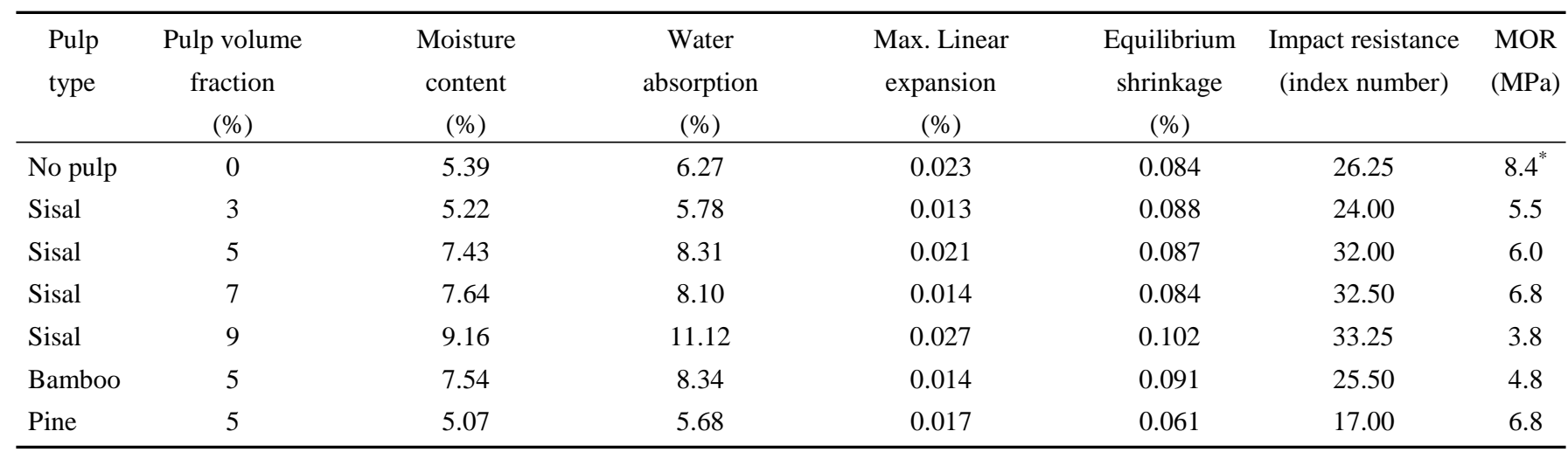

${ }^{*}$ The control composite contained MRHA

were kept constant and equal to, respectively, $0.40 ; 2.0$ and $2.4 \%$ of cementitious material by weight. The durability of the composites was investigated by simulated ageing cycles. It was observed that after being subjected to 48 simulated ageing cycles (each cycle consisted of wetting the specimens for $30 \mathrm{~min}$, followed by heating in an oven at a temperature of $105^{\circ} \mathrm{C}$ for five and a half hours) the decreasing in modulus of rupture for the sisal pulp-mortar composite was smaller than that of the control composite. The results also showed that the use of pulp and MRHA in the mortar matrix considerably increased the durability of the composite. Comparison of results with those of other pulp mortar composites, sisal pulp-matrix composites containing $5 \%$ pulp volume fraction showed the highest modulus of toughness. It was concluded that sisal pulp-mortar composites were impervious, durable, possessed high strength and good impact resistance, and therefore can be considered as a suitable substitute for asbestos-fibre board.

Coutts \& Warden [1992] have reported on the use of sisal pulp prepared by the kraft and soda process as reinforcement in cement mortar composites. The physical and mechanical properties of the composites were evaluated with a view to make use of these materials as building products. These properties are presented in Table 10.

Berhane $(1987,1994)$ have reviewed the durability of mortar roofing sheets reinforced with sisal fibres and reported that the service life of roofing sheets made of Portland cement mortar reinforced sisal fibres is very short, especially in hot-humid climatic conditions. It was noticed that pozzolanic materials have a protective effect on sisal fibres in the cement composites.

Ghavami \& Toledo Filho (1994, 1995), Tolêdo Filho \& Ghavami (1996), England and Tolêdo Filho (1997) and Tolêdo Filho (1997) have studied both the short-term and long-term behavior of sisal fibre reinforced mortar composites. The experimental work involved extensive laboratory testing to study the influence of volume fraction, fibre length, fibre arrangement and matrix composition on the mechanical properties of the composite. The workability of the fresh mix was shown to be closely related to the volume fraction and fibre aspect ratio. An increase in fibre volume fraction and fibre length reduced the workability of the mix. It was established that, for volume fractions smaller than $3 \%$ and fibre length smaller than $50 \mathrm{~mm}$, the mixes could be manually compacted or vibrated without balling.

The mode of failure and the properties of the resistance to fibre-matrix interfacial bonding were determined using the single fibre pull-out test. Both fibre fracture and fibre pull-out were found to occur in sisal fibre reinforced mortar composites. Specimens with short embedment length tended to pull out whereas those with long embedment length tended to fail in tension. As most of the systems with fibre embedment length greater or equal to $25 \mathrm{~mm}$ failed by fibre fracture, this length can be suggested as a critical length for sisal fibres. The replacement of OPC by silica fume and slag increased the value of the debonding load by about $24 \%$ and the maximum pull-out or fibre breaking load by about 9 to $20 \%$. This increase in debonding and maximum load has been related to the fineness of the fillers that reduced the porosity of the transition zone, improving the fibre-matrix bonding.

Addition of sisal fibres to cement mortar matrices reduced the compressive strength by 18.4 to $32 \%$, the elastic modulus by 1.3 to $15 \%$, the longitudinal strain capacity at ultimate stress by 15.2 to $32.9 \%$, and the lateral strain capacity by 4.2 to $24.9 \%$. On the other hand, the descending branch of the stress-strain curve of the matrices presented a less steep slope which indicates a material with higher ductility and toughness (Figure 5). Poisson's ratio was not significantly affected by fibre reinforcement. The partial replacement of OPC by slag and silica fume led to mixes with a compressive strength slightly higher than those made with OPC. The presence of slag and silica fume in the mixes 
Table 10. Kraft and soda sisal pulp reinforced cement mortar (Coutts and Warden, 1992)

\begin{tabular}{|c|c|c|c|c|c|c|c|c|c|c|}
\hline \multirow[t]{2}{*}{$\begin{array}{l}\text { Fibre content } \\
(\% \text { by wt) }\end{array}$} & \multicolumn{2}{|c|}{$\begin{array}{c}\text { Flexural } \\
\text { strength } \\
(\mathrm{MPa})\end{array}$} & \multicolumn{2}{|c|}{$\begin{array}{c}\text { Fracture } \\
\text { toughness } \\
\left(\mathrm{kJ} \mathrm{m}^{-2}\right)\end{array}$} & \multicolumn{2}{|c|}{$\begin{array}{c}\text { Flexural } \\
\text { modulus } \\
(\mathrm{GPa})\end{array}$} & \multicolumn{2}{|c|}{$\begin{array}{c}\text { Water } \\
\text { absorption } \\
(\%)\end{array}$} & \multicolumn{2}{|c|}{$\begin{array}{l}\text { Density } \\
\left(\mathrm{g} \mathrm{cm}^{-3}\right)\end{array}$} \\
\hline & Kraft & Soda & $\overline{\text { Kraft }}$ & Soda & $\overline{\text { Kraft }}$ & Soda & Kraft & Soda & $\overline{\text { Kraft }}$ & Soda \\
\hline 0.5 & 9.7 & - & 0.25 & - & 10.1 & - & 13.6 & - & 1.82 & - \\
\hline 1.0 & 9.9 & - & 0.45 & - & 9.1 & - & 15.2 & - & 1.76 & - \\
\hline 1.5 & 11.3 & - & 0.62 & - & 8.5 & - & 15.8 & - & 1.69 & - \\
\hline 2.0 & 12.7 & 12.2 & 0.84 & 0.36 & 9.3 & 17.3 & 17.1 & 14.9 & 1.69 & 1.83 \\
\hline 4.0 & 15.9 & 17.4 & 1.64 & 1.53 & 10.1 & 12.5 & 19.0 & 19.7 & 1.59 & 1.64 \\
\hline 6.0 & 16.7 & 18.0 & 2.05 & 2.57 & 7.8 & 9.5 & 23.5 & 22.0 & 1.47 & 1.55 \\
\hline 8.0 & 18.3 & 17.9 & 2.49 & 2.63 & 6.5 & 8.4 & 27.6 & 24.4 & 1.37 & 1.45 \\
\hline 10.0 & 15.0 & 14.2 & 2.47 & 2.36 & 5.3 & 5.8 & 22.4 & 26.3 & 1.50 & 1.39 \\
\hline 12.0 & 10.3 & 12.6 & 3.07 & 2.59 & 4.5 & 4.9 & 24.5 & 28.3 & 1.45 & 1.35 \\
\hline
\end{tabular}

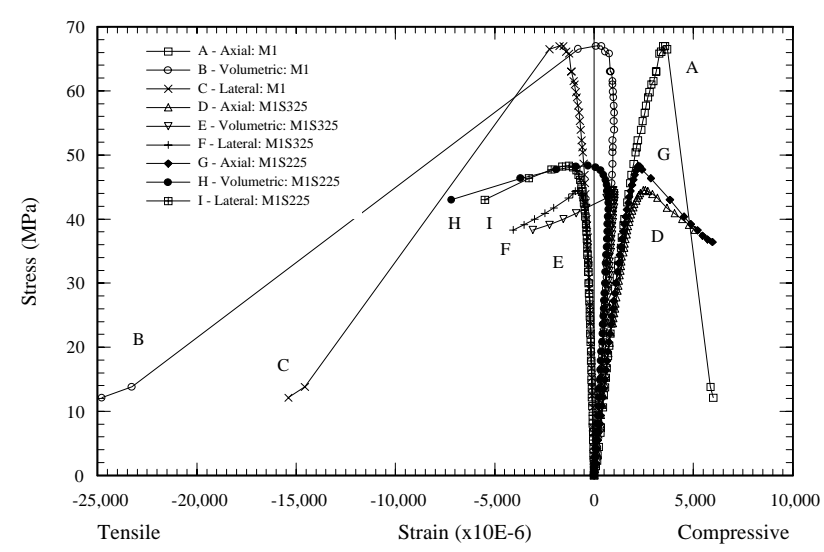

Figure 5. Stress-strain relationships for mortar (M1) without and with 2\% (M1S225) and 3\% (M1S325) of sisal fibres $25 \mathrm{~mm}$ long (Tolêdo Filho, 1997)

resulted in both reduction and increase of the elastic modulus, whereas the Poisson's ratio was not significantly changed (Tolêdo Filho, 1997).

Indirect tension splitting tests were performed on mortar with and without sisal fibres. Generally, the inclusion of fibres increased the tensile stress at splitting failure. Flexural loaddeflection behavior of natural fibre-reinforced mortar composites was investigated by the author using prismatic specimens (100 x $100 \times 400 \mathrm{~mm}$ ) over a span of $300 \mathrm{~mm}$ under third-point loading. Figure 6 presents load-deflection curves for different fibre volume, length and alignment.

The flexural behavior of natural fibre-reinforced mortar composites may be explained using the approach proposed by Kobayashi and Cho (1981) for the bending characteristics of polyethylene fibre-reinforced concrete, since both kind of fibres exhibit modulus of elasticity smaller than that of the matrix. A schematic flexural load-deflection curve was given as in Figure 7. It was divided into different regions based on the fracture process, to discuss the load carrying mechanism.

The load-deflection curves may generally be divided into two parts: region I which is the elastic range before cracking, and region II which is the inelastic range until fracture. In region I it is considered that only the matrix carries load. Because the modulus of elasticity of the fibre is low compared with that of the matrix, the fibres do not work to prevent cracking. In region II, only fibres carry tensile stresses as in conventional reinforced concrete. This region may be subdivided into three parts: the region "a" where load is transmitted from concrete to fibres, the region " $b$ " where fibres carry all the tensile forces, and thereby increase the loading carrying capacity and the region "c" where

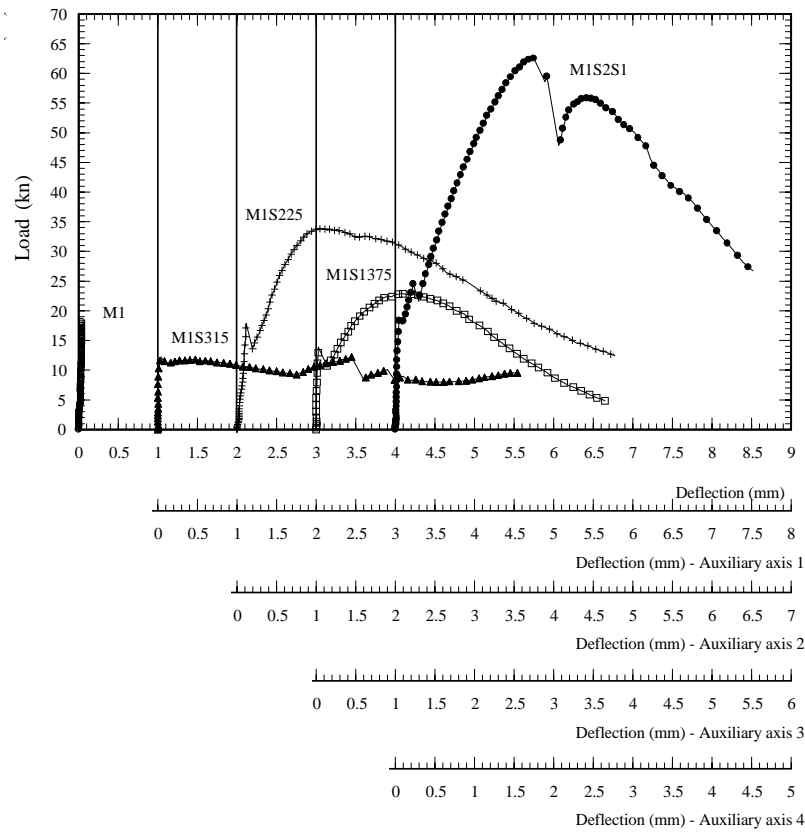

Figure 6. Load-deflections responses for the matrix (M1), for the matrix reinforced with 3\% of sisal fibres $15 \mathrm{~mm}$ long (M1S315), for the matrix reinforced with $2 \%$ of sisal fibres $25 \mathrm{~mm}$ long (M1S225), for the matrix reinforced with $1 \%$ of aligned sisal fibres $375 \mathrm{~mm}$ long (M1S375), for the matrix reinforced with $2 \%$ of sisal fibres $25 \mathrm{~mm}$ long and with $1 \%$ of aligned sisal fibres 375 mm long (M1S2S1) (Toledo Filho, 1997)

the load carrying capacity decreases because of rupture or slipping of fibres until fracture. In region "a", the tensile forces carried by the matrix are transmitted to fibres after cracking. Immediately after cracking, fibres which virtually have not carried any load before cracking and have low modulus of elasticity cannot carry the entire load carried by the matrix before cracking. Therefore, the load carrying capacity temporarily decreases. The amount of decrease $\left(\mathrm{P}_{\mathrm{cr}}-\mathrm{P}_{\mathrm{o}}\right)$ can be affected, for example, by fibre length, volume fraction, arrangement, loading velocity, and matrix strength. In region "b", the fibres carry all the tensile forces, and the load carrying capacity is recovered as fibres stretch with increase in deflection. A maximum load carrying capacity " $\mathrm{P}_{\max }$ " which exceeds the cracking load may be reached depending on the fibre length, volume fraction and arrangement. In region "c", fibre reinforced mortar gradually loses its load carrying capacity because of fibre pull out or rupture and finally fracture occurs. 


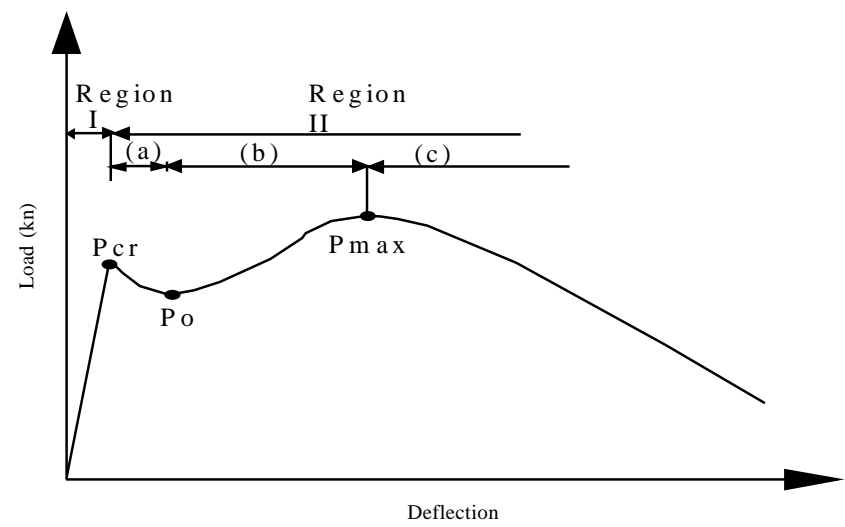

Figure 7. Schematic flexural load-deflection curve of polypropylene fibre reinforced concrete (Kobayashi and Cho, 1981)

Observing the load-deflection curves presented in Figure 6 it can be seen that, except for the mix M1S315, all curves have a shape quite similar to the schematic load-deflection curve shown in Figure 7. They also demonstrate the strength improvement to be gained after first cracking due to fibre addition. When a proportion of the fibres is deliberately aligned with the longitudinal axis of the beam, namely test M1S2S1 with $1 \%$ of aligned fibres and $2 \%$ randomly orientated, considerable enhancement of the load carrying capacity was produced; a three-fold increase over the un-reinforced mortar strength in this test.

The long-term properties of the sisal fibre reinforced-mortar composites were assessed by Tolêdo Filho (1997) throughout creep, shrinkage and durability tests. The influence of the addition of sisal fibres, of various volume fractions and lengths, on the creep of a mortar matrix was determined using sealed and unsealed specimens subjected to a pressure of 14.4 MPa over a period of 210-350 days. Recovery strains were recorded for a period of 56-180 days. The influence of volume fraction, fibre lengths, cure types, mix proportions and replacement of OPC by slag and silica fume on the dimensional stability of mortar matrices was determined using drying shrinkage tests for a period of 320 days.

The addition of sisal fibre to the matrix reduced its ability to creep (flow) and had little or no effect on the delayed elastic strains. The presence of fibres appears to create moisture paths deep into the mortar which enhance the route of moisture loss and aid the development of higher shrinkage strains. Sisal fibre reinforcement increased the shrinkage of the matrix by about $0 \%$ to $27 \%$. The mixes with slag and silica fume presented an initial rate of shrinkage smaller than that observed for the mix made with OPC (especially specimens with silica fume). After 320 days, the shrinkage of the silica fume-cement specimens approached that of the OPC specimens and still presented a tendency to increase the shrinkage. This behavior may occur because slag-cement matrices and, even more so, silica fume-cement matrices have lower permeability than OPC matrices, resulting in a slow rate of moisture loss and hence shrinkage, with time.

The durability of fibre-reinforced mortars after 320 to 360 days, stored under water, exposed to cycles of wetting and drying as well as to outdoor weathering, was assessed by Tolêdo Filho (1997) from results of flexural tests and from observations of the photo-micrographs obtained using backscattered imaging and secondary electron imaging. Composites manufactured with short sisal fibres and OPC matrix presented a significant reduction in toughness after 6 months of ageing outdoors or submitted to cycles of wetting and drying. Some embrittlement was also observed in specimens aged in water. The embrittlement is mainly associated with lignin decomposition and mineralization of the fibres due to migration of hydration products, especially calcium hydroxide, to the fibre lumen and spaces, and seems to happen at a higher rate for short fibres. Several treatments to enhance the durability performance of the composites were studied by the author. The treatments included: (a) modifications to the matrix through the replacement of Portland cement by undensified silica fume and by blast-furnace slag; (b) carbonation of the cementitious matrix and (c) immersion of the fibres in slurry silica fume prior to being incorporated into the Portland cement matrix. The results obtained indicated that the embrittlement of the composites can be avoided almost completely by immersing sisal fibre in a silica fume slurry before adding them to the mix. The early cure of the composites in a $\mathrm{CO}_{2}$ rich environment and the replacement of OPC by undensified silica fume also are efficient approaches for reducing the embrittlement of the composite. The use of slag as a cement replacement had no effect on reducing the embrittlement of the composites.

Sanjuan and Tolêdo Filho (1998) have studied the influence of fibre reinforcement in controlling free and restrained shrinkage during the early age of mortar mixes; cracking due to restraint, the phenomenon of crack self-healing and the effectiveness of crack control at early age on the corrosion of steel bars in low modulus sisal fibre reinforced mortar composites. Limiting free plastic shrinkage strains of $2300 \mu \varepsilon$ and $1700 \mu \varepsilon$ were recorded at $300 \mathrm{~min}$ after casting for a 1:2:0.45 mortar (proportions by weight of cement, sand and water) with and without $0.2 \%$ sisal fibre $25 \mathrm{~mm}$ long.

Restrained shrinkage experiments were performed using ringtype specimens with a central square core. Five rods connected the ring to the core. This arrangement initiated plastic shrinkage cracking from the core (Figure 8). Recording were made for specimens kept on an accelerated drying environment (air flow of $0.4 \mathrm{~m} / \mathrm{s}$ at $40^{\circ} \mathrm{C}$ ) for a period of $210 \mathrm{~min}$ from casting.
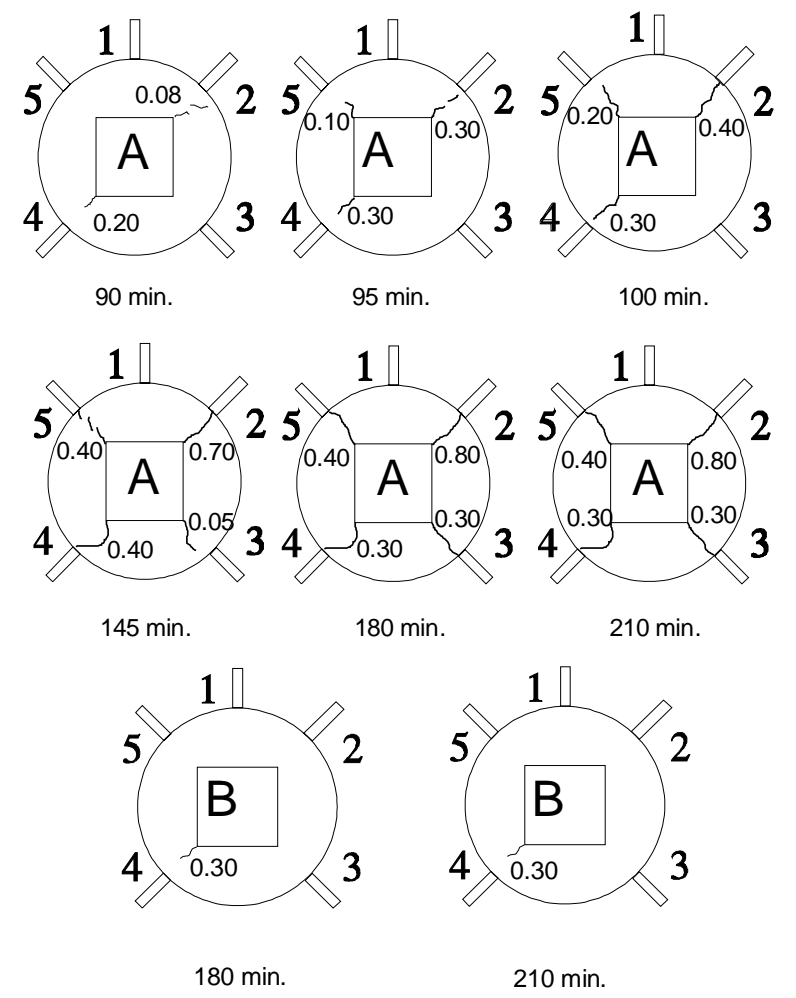

Figure 8. Shrinkage crack pattern at early ages. Mortar only, A; and composite with $0.2 \%$ sisal fibres, B. Numbers adjacent to crack indicate crack widths in mm (Sanjuan \& Toledo Filho, 1998) 
Healing of the cracks was observed holding the specimens at $100 \% \mathrm{RH}$ and room temperature $\left(\mathrm{T}=22^{\circ} \mathrm{C}\right)$ for a period of 40 days. The results in Figure 9 show that little or no healing took place for the unreinforced mortar while almost complete healing occurred for the composite specimens. Clearly sisal fibres acted as porous bridging elements across cracks and permitted the deposition of new hydration products and the subsequent infill/ closure of the cracks.
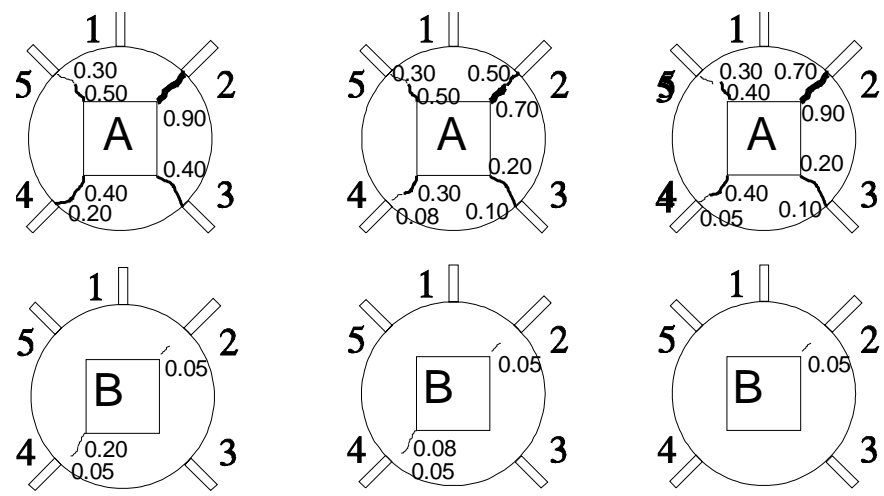

Figure 9. Changes of shrinkage crack pattern up to an age of 40 days, due to healing of cracks in a $100 \% \mathrm{RH}$ condition (Sanjuan \& Toledo Filho, 1998)

After 40 days held at a $100 \% \mathrm{RH}$ at room temperature the plain mortar and sisal fibre-mortar samples with reinforcing bars were exposed to a chloride solution to enhance the corrosion rate of the steel bars. The corrosion of the steel bars was monitored by electrochemical measurements and observations of crack development. Natural fibres performed well in controlling cracks in mortars and also delayed the initiation of the corrosion of embedded steel bars. From their experiments the authors concluded that the inclusion of sisal fibres inhibited early age cracking and provided a suitable mechanism for subsequent healing in the hardened and wet final state.

\section{CONCLUSIONS}

From the results presented in this review, it becomes evident that cement based matrices reinforced with sisal fibres are on the horizon, thus bringing new trends in composite materials. But to make this a reality, some conditions may have to be met. Of particular importance are the following: (i) development of efficient methods of fibre extraction, pretreatment of fibres and conversion in usable forms (filaments, mats, fabrics, rovings, etc.) (ii) development of production techniques for manufacture keeping in view that it must be cost-effective; (iii) since longterm performance is one of the major limitations, durability must be properly assessed and processes should be developed to minimize this limitation; (iv) physical and mechanical properties, impact and abrasive resistance, water absorption, shrinkage, chemical resistance, acoustic requirements, thermal performance and durability of sisal fibre cement based products should be thoroughly evaluated so as to arrive at a series of composites to be used in rural and civil construction (iv) design procedures must also be standardized.

\section{REFERENCES}

ARGON, A. S.; SHACK, W. J. Theories of fibre cement and fibre concrete. In: RILEMSYMPOSIUMONFIBREREINFORCED CEMENT AND CONCRETE. London: The Construction Press, 1975, p. 39-52.

AZIZ, M. A.; PARAMASIVAM, P.; LEE, S.L. Prospects for natural fibre reinforced concretes in construction. The International Journal of Composites and Lightweight Concrete, London, v. 3, n. 2, p. 123-132, May, 1981.

AZIZ, M. A.; PARAMASIVAM, P.; LEE, S.L. Concrete reinforced with natural fibres. In: SWAMY, R. N. ed. Natural fibre reinforced cement and concrete. London: Blackie and Son Ltd, 1984, v. 5, chapter 3, p. 106-140.

BALAGARU, P. N.; SHAH, S.P. Fiber-reinforced cement composites. New York: McGraw-Hill, 1992.530p.

BALUCH, H.; ZIRABA, Y.N; AZAD, A.K. Fracture characteristics or sisal fibre reinforced concrete. The International Journal of Composites and Lightweight Concrete, London, v. 9, n. 3, p. 157-168, August, 1987.

BEAUDOIN, J. J.; Handbook of fiber-reinforced concrete. U.S.A.: Noyes Publications, 1990. 332p.

BENTUR, A.; MINDESS, S. Fibre reinforced cementitious composites, Elsevier Applied Science, U.K, 1990, 449p.

BERGSTRÖN, SVEN G., HANS-ERIK GRAM. Durability of alkali-sensitive fibres in concrete. The International Journal of Composites and Lightweight Concrete, London, v. 6, n. 2, May, p. 75-80, 1984.

BERHANE, Z.; Durability of mortar roofing sheets reinforced with natural fibre. SYMPOSIUM ON BUILDING MATERIALS, FOR LOW-INCOME HOUSING, Bangkok: Thailand, Jan. 20-26, 1987, p. 321-327.

BERHANE, Z. Performance or natural fibre reinforced mortar roofing tiles. Materials and Structures, Paris, v. 27, p. 347-352, 1994.

BESSEL, T. J.; MUTULI, S.M. The interfacial bond strength of sisal-cement composites using a tensile test. Journal of Materials Science Letters, London, n. 1, p. 244-246, 1982.

BRU DATA SHEET. Roof sheets made of sisal reinforced concrete. Dar es Salaam: Building Research Unit, p. 1-8, 1978.

BUILDING RESEARCH STATION NEWS (BRS). Poor outlook for sisal. U.K. BRS News, n. 14, 1970.

CANOVAS, M.F.; KAWICHE, G.M.; SHELVA, N.H. Possible ways of preventing deterioration of vegetable fibres in cement mortars. VEGETABLE PLANTS AND THEIR FIBRES AS BUILDING MATERIAL. Proceeding... No. 7, Rilem, Salvador, 1990.

CANOVAS, M. F.; SELVA, N.H.; KAWICHE, G.M. New economical solutions for improvement or durability of Portland mortars reinforced with sisal fibres. Materials and Structures, Paris, v. 25, p. 417-422, 1992.

CAPPELEN, P. Roof sheets made of sisal reinforced concrete. Building Research Unit, Ministry of Lands Housing and Urban Development. Working Report, WR 14, p. 1-7, July, 1978.

CARVALHO FILHO, A. C. Mortar reinforced with sisal: mechanical behavior in flexure. In. VEGETABLE PLANTS AND THEIR FIBRES AS BUILDING MATERIAL. Proceeding... No. 7, Rilem, Salvador, 1990. 
CHATVEERA, B.; NIMITYONGSKUL, P. Influence of rice husk ash on properties of sisal pulp-mortar composites. ACI Special Publication, SP 154-11, Farmington Hills, p. 211-228. 1987.

COUTTS, R.S.P.; WARDEN, P.G. Sisal pulp reinforced cement mortar. Cement \& Concrete Composites, v.14, p. 17-21. 1992.

ENGLAND, G.L.; TOLÊDO FILHO, R.D. Natural fibre reinforced concrete. In: ASIA-PACIFIC SPECIALTY CONFERENCEON FIBREREINFORCEDCONCRETE. Singapore, p. 55-70. 1997.

GHAVAMI, K.; TOLÊDO FILHO, R.D. Mechanical properties of composites reinforced with sisal fibre. FIRST INTERNATIONAL CONFERENCE ON COMPOSITE ENGINEERING, 1., New Orleans, August, p. 721-722, 1994.

GHAVAMI, K.; TOLÊDO FILHO, R.D. Experimental analysis of cement mortar composites reinforced with natural fibres. SECOND INTERNATIONAL CONFERENCE ON COMPOSITE ENGINEERING, 2., New Orleans, August, 1995, p. 247-248.

GRAM, H.E. Durability of natural fibres in concrete. Swedish Cement and Concrete Research Institute, Research Fo. 1:83, 1983, 225 p.

GRAM, H.E. Natural Fibre Concrete Roofing, In: R.N. Swamy ed. Natural fibre reinforced cement and concrete. London: Blackie and Son Ltd., 1988, Vol. 5, p. 256-285.

GUIMARÃES, S. S. Experimental mixing and moulding with vegetable fibre reinforced cement composites. In: Ghavami K.; Fang, H. Y. ed. INTERNATIONAL CONFERENCE ONDEVELOPMENT OFLOW-COSTEND ENERGY SAVING CONSTRUCTION MATERIALS, 1984, Rio de Janeiro, p. 37-52.

GUIMARÃES, S. S. Some experiments in vegetable fibre-cement composites. SYMPOSIUM ON BUILDING MATERIALS, FOR LOW-INCOME HOUSING, Bangkok, Thailand, Jan. 2026, 1987.20-26, pp. 167-175.

JOSEPH, K.;TOLEDO FILHO, R. D.; JAMES, B.; THOMAS, S.; CARVALHO, L.H. The use of sisal fibre as reinforcements in polymer in composites, Brazilian Journal of Agricultural and Environmental Engineering, 1999. Submitted

KOBAYASHI, K.; CHO, R. Flexural behavior of polyethylene fibre reinforced concrete, International Journal of Cement Composites and Lightweight Concrete, London, v. 3, February, p-19-25, 1981.

MAWENYA, A.S.; MWAMILA, B.L.M. Characteristics of sisal as a reinforcing fibre. Faculty of Engineering, University of Dar es Salaam, p. 1-22, 1979.

MORRISSEY, F.E.; COUTTS, R.S.P. Bond between cellulose fibres and cement. The International Journal of Composites and Lightweight Concrete, London, v.7, n.2, May, p-73-80, 1985.

MUKHERJEE, K.G.; SATYANARAYANA, K.G. Structure and properties of some vegetable fibres. Part 1: Sisal fibre. Journal of Materials Science, London, v.19, p. 3925-3934, 1984.

MWAMILA, B.L.M. Flexural behaviour of concrete elements reinforced with sisal fibres. Dar es Salaam: University of Dar es Salaam, 1979. 185p. M.Sc. Thesis

MWAMILA, B.L.M. Natural Twines as Main Reinforcement in Concrete Beams, The International Journal of Composites and Lightweight Concrete, London, v.7, February, p-11-19, 1985.

MWAMILA, B.L.M. Characteristics of natural fibrous reinforcement in cement-based matrices. SYMPOSIUM ON BUILDING MATERIALS, FOR LOW-INCOME HOUSING, Bangkok, Thailand, Jan. 20-26, 1987. p. 87-93.
NILSSON, L. Reinforcement of concrete with sisal and other vegetable fibres. Stockholm: Swedish Council for Building Research, 1975, 68p. Document No D-14

PARTEK AB. Research Laboratory in Pargas, Finland, 1979.

PERSSON, H.; SKARENDAHL, A. Sisal-fibre concrete for roofing sheets and other purposes. Appropriate industrial technology for construction and building materials. New York: United Nations, 1980. Monographs on Propriety Industrial Technical. No. 12

ROMAULDI, J.P.; BATSON, G.B. Mechanics of crack arrest in concrete. Journal of the Engineering Mechanics Division, Proceedings of the ASCE, v. 89, n. EM3, p. 147-168, Jun. 1963

SANJUÁN. M.A.; TOLÊDO FILHO, R.D. Effectiveness of crack control at early age on the corrosion of steel bars in low modulus sisal and coconut fibre-reinforced mortars. Cement and Concrete Research, v. 28, n. 4, p. 555-565, 1998.

SAVASTANO JUNIOR, H.; AGOPYAN, V. Transition zone on hardened cement paste and vegetable fibre. In: Swamy, R. N. ed. FIBREREINFORCEDCEMENT AND CONCRETE, 1992. RILEM. London.

SCHAFER, H. G.; BRUNSSEN, G.W. Sisal fibre reinforced lost form work for floor slabs. In: VEGETABLE PLANTS AND THEIR FIBRES AS BUILDING MATERIAL. 7., Proceeding... Rilem, Salvador, 1990.

SWIFT, D.G., Sisal-cement composites and their potential for rural Africa. In: I. H. Marshall ed. COMPOSITE STRUCTURES 3, Elsevier Science Publishers, 1985, pp. 774-787.

SWIFT, D.G.; SMITH, R.S.L. Sisal fibre reinforcement of cement paste and concrete. In: MATERIALS OF CONSTRUCTION FOR DEVELOPING COUNTRIES. Bangkok, August, 1978, p. 221-233.

SWIFT, D.G.; SMITH, R.S.L. Sisal-cement composites as lowcost construction materials. Appropriate Technology, London, v. 6, n. 3, p.6-8, November. 1979a.

SWIFT, D.G.; SMITH, R.S.L. The flexural strength of cementbased composites using low modulus (sisal) fibres. Composites, London, v. 6, n. 3, p. 145-148, July, 1979b.

TOLÊDO FILHO, R.D. Natural fibre reinforced mortar composites: Experimental characterisation, Rio de Janeiro: DEC/PUC, 1997, 472p. Ph.D. Thesis

TOLÊDO FILHO, R.D. Utilização da fibra de sisal na construção civil. In: Silva, O.R.R.F.; Beltrão, N.E.M. eds. O agronegócio do sisal no Brasil. Brasília: Embrapa/CNPA, 1999, p. 177-202.

TOLÊDO FILHO, R. D.; GHAVAMI, K. Tensile properties of sisal and compression behaviour of cement mortar sisal composite. INTERNATIONAL CONFERENCE ON COMPOSITE ENGINEERING, 3., 1996, New Orleans, Agosto.

ZONSVELD, J.J. Properties and testing of concrete containing fibres other than steel. In: RILEM SYMPOSYUM ON FIBRE REINFORCED CEMENT AND CONCRETE. London, The Construction Press, 1975. p. 217-226. 